\title{
Antibacterial Activity of Ethanol Extract of Betel Leaf (Piper betle L.) Against Some Food Borne Pathogens
}

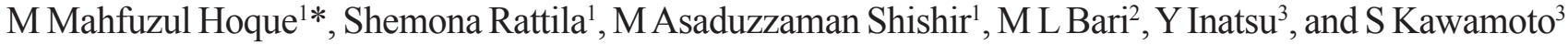 \\ ${ }^{I}$ Department of Microbiology, University of Dhaka, Dhaka-1000, Bangladesh, ${ }^{2}$ Centre for Advanced Research in Sciences, University of Dhaka, \\ Dhaka-1000, Bangladesh, ${ }^{3}$ NFRI, Tsukuba, Ibaraki, Japan
}

(Received 14 July 2011; Accepted 22 October 2011)

\begin{abstract}
The ethanol extract of Betel leaf (Piper betle L.), an indigenous climber plant of Bangladesh was screened for its antibacterial activity against some foodborne pathogens viz. Vibrio cholerae ATCC 6395, E. coli ATCC 25922, E. coli 0157:H7 NCTC 12049, Shigella dysenteriae-1 MJ-84 and Staphylococcus aureus ATCC 25923. Experimental findings revealed that the ethanol extract of betel leaves potentially inhibit the growth of these foodborne pathogens. Minimum inhibitory concentration (MIC) was ranged from $0.625 \%$ (w/v) to $0.75 \%(w / v)$. The ethanol extract of betel leaf showed the highest MIC values for E. coli ATCC 25922 (0.625 mm), Vibrio cholera ATCC $6395(0.625 \mathrm{~mm})$, and Staphylococcus aureus ATCC $25923(0.625 \mathrm{~mm})$. It was revealed that the antibacterial activity was highest at around neutral $\mathrm{pH}$ and at moderate temperature. The highest temperature $\left(100^{\circ} \mathrm{C}\right)$ and the $\mathrm{pH}(10.0)$ treated ethanol extract showed a little less activity than the maximum activity at moderate temperature and at neutral $\mathrm{pH}$, suggesting that the ethanol extract of the betel leaf was to some extent high temperature and high pH tolerant. The ethanol extract of betel leaf might have a potential application as natural food preservative to improve the microbiological safety of the foods.
\end{abstract}

Key words: Antibacterial activity, ethanol extract, essential oil, betel leaf, food borne pathogen

\section{Introduction}

Herbal medicine are traditionally used worldwide for the treatment of many infectious diseases. The use of medicinal plants as novel antibiotics have several other advantages related to safety, availability, and minimizing the risk of side effects and addiction ${ }^{1}$. The World Health Organization (WHO) has adopted a major policy change in accepting that most developing nations would have to make use of more traditional medical practices for primary health care ${ }^{2}$.

In recent years, multi drug resistance in human, animal and plant pathogens have developed due to misuse of antibiotics commonly applied in the treatment of infectious diseases ${ }^{3-5}$. Among food-borne pathogens, the prevalence of antimicrobial resistance has increased during recent decades ${ }^{6-9}$. This alarming situation has led microbiologists to search for new antimicrobial compounds from various sources, including medicinal plants ${ }^{10}$.

Piper betle L. Piperaceae) leaves is widely used as a mouth freshener after meal. This plant is extensively grown in Bangladesh, India, Sri Lanka, Malaysia, Thailand, Taiwan and other Southeast Asian countries. Its common name is betel in English, paan in India and Bangladesh, phlu in Thailand and sirih in Bahasa Indonesian ${ }^{11}$. Betel leaf is edible that has achieved an esteemed position in the human society right from the dawn of civilization, particularly in Bangladesh, Burma, China, India,
Indonesia, Malaysia, Nepal, Pakistan, Philippines, South Africa, Sri Lanka, Thailand etc. ${ }^{12-15}$, where strong pungent aromatic flavoured leaves are traditionally used for chewing in their natural raw condition along with many other ingredients like sliced areca nut, slaked lime, coriander, aniseed, clove, cardamom, sweetener, coconut scrapings, ashes of diamond, pearl, gold and silver (Ayurvedic preparations), jelly, pepper mint, flavouring agent, fruit pulp etc. by the people ${ }^{16}$. Indian system of medicine and health has adopted the use of betel leaves in various ways. In Indian folkloric medicine, betel leaf is popular as an antiseptic and is commonly applied on wounds and lesions for its healing effects. Essential oil extracted from betel leaf may be used as an industrial raw material for manufacturing medicines, perfumes, mouth fresheners, tonics, food additives etc ${ }^{17}$. The leaves have also been used in traditional medicine as carminative, stimulant, antiseptic, antifungal, and antibacterial agent ${ }^{18}$.

Previous studies on the betel leaves, roots and whole extract (mixture of volatile and non-volatile) of the green variety showed a very strong antimicrobial activity ${ }^{19}$. These plant extracts were also used to cure urinary tract infections, cervicitis vaginitis, and gastrointestinal disorders ${ }^{20}$ and skin infections such as herpes simplex virus type- $1^{21}$. Its leaf is traditionally known to be useful for the treatment of various diseases like bad breath, boils and abscesses, conjunctivitis, constipation, headache, hysteria, itches, mastitis, mastoiditis, leucorrhoea, ringworm, swelling of 
gum, rheumatism, abrasion, cuts and injuries etc. as folk medicine while the root is known for its female contraceptive effects ${ }^{22,13}$.

This study was conducted to observe the antibacterial activity of the ethanol extract of the betel leaves against some food borne pathogens.

\section{Materials and Methods}

Plant

Betel leaves (Piper betle L., family- Piperaceae) were tested for antibacterial activity. Leaves of the betel plant were collected from local market of Dhaka Metropolitan City.

\section{Test organisms and Maintenance}

Vibrio cholerae ATCC 6395, E. coli ATCC 25922, Staphylococcus aureus ATCC 25923, E. coli O157:H7 NCTC 12049, and Shigella dysenteriae-1 MJ-84, was obtained from American Type Culture Collection, National Collection of Type Culture, and the Department of Microbiology, University of Dhaka, respectively. The stock cultures of the test organisms in medium containing $20 \%$ glycerol in cryogenic vials (Apogent Company) were kept at $-70^{\circ} \mathrm{C}$. Working cultures were kept at $4^{\circ} \mathrm{C}$ on tryptic soy agar (TSA) slants (NISSUI, Tokyo, Japan) and were periodically transferred to fresh slants. A loopful of culture from the slant was transferred to Tryptic soy broth (TSB) and grown overnight at $37^{\circ} \mathrm{C}$. The overnight grown culture was used for the subsequent study.

\section{Media and Chemicals}

Mueller-Hinton Broth (MHB) and Agar (MHA), Trypticase Soya Broth (TSB) and Trypticase Soya Agar (TSA), ciprofloxacin (NISSUI pharmaceuticals Co. Ltd. Japan) were used for this study.

\section{Preparation of ethanol extract of betel leaves}

The betel leaves were cut in small pieces; washed in distilled water; dried at $40^{\circ} \mathrm{C}$ for 48 hours in an oven (Barnstead/Lab-Line; USA; Model No. 121; Serial No, 0203-1541). The dried leaves were grounded using a mortar and pestle into fine powder. Twenty grams of betel leaf powder were soaked in $80 \mathrm{ml}$ of $95 \%$ ethanol in sterilized bottle and kept in fume hood chamber for overnight. The ethanol fraction was separated using sterilized cheesecloth and filtered through sterilized Whatman filter paper (No.3).

\section{Preparation of the McFarland standard}

A $0.5 \mathrm{McF}$ arland standard was prepared by mixing $0.05 \mathrm{ml}$ of $1.175 \%$ barium chloride dihydrate $\left(\mathrm{BaCl}_{2} \cdot 2 \mathrm{H}_{2} \mathrm{O}\right)$, with $9.95 \mathrm{ml}$ of $1 \%$ sulfuric acid $\left(\mathrm{H}_{2} \mathrm{SO}_{4}\right)^{24}$ in a test tube with constant stirring. The tube was then sealed tightly stored in the dark at room temperature to prevent loss by evaporation.

\section{Antibacterial sensitivity testing}

The antibacterial activity of the ethanol extract was done according to the method of Bauer et al. (1966) ${ }^{25}$. The 8-mm diameter discs (Advantec; Toyo Roshi Kaisha, Ltd., Tokyo, Japan) were impregnated with $50 \mathrm{ml}$ of ethanol extract from $10 \mathrm{mg} / \mathrm{ml}(\mathrm{w} /$ v) solution of and were dried at $40^{\circ} \mathrm{C}$ in a dry oven (Model No.121, Sl. No.- 0203-1541, 1999, Burnstead Lab-Line, USA) before being placed on the inoculated agar plates. The inocula of the test organisms were prepared by transferring a loopful of culture in TSA into $9 \mathrm{ml}$ of sterile Mueller Hinton broth (Difco, Sparks, MD) and incubated at $37^{\circ} \mathrm{C}$ for 5 to 6 hours. The bacterial cultures were compared with McFarland turbidity standard $\left(10^{8} \mathrm{CFU} / \mathrm{ml}\right)^{24}$ and streaked evenly in three directions keeping at a $60^{\circ}$ angle onto the surface of the Mueller Hinton agar plate $(10 \times 40 \mathrm{~mm})$ with sterile cotton swab. Surplus suspension was removed from the swab by rotating the swab against the side of the tube before the plate was seeded. After the inocula dried, the impregnated discs were placed on the agar using sterile forceps and were gently pressed down to ensure contact. For each plate 5 discs were placed and were placed in a way so that they were no closer than $24 \mathrm{~mm}$ (Fig.1). Plates were kept at refrigeration temperature for 30 minutes for better absorption. During this time microorganisms will not grow but absorption of extracts would take place. Negative controls were prepared using the same solvent without the ethanol extract. Reference antibiotic such as ciprofloxacin $(30 \mathrm{mg} / \mathrm{disc})$ were used as positive controls. The inoculated plates containing the impregnated discs were incubated in an upright position at $37^{\circ} \mathrm{C}$ overnight and/or 24 to 48 hours. The results were expressed as the diameter of inhibition zone around the paper disk $(8 \mathrm{~mm})$.

\section{Determination of $M I C$ and $M B C$}

The MIC of the ethanol extract of betel leaf was determined by tube dilution techniques in Mueller-Hinton broth according to Sengul et al. $(2005)^{26}$. Inoculates were prepared in the same medium at a density adjusted to $0.5 \mathrm{McF}$ arland turbidity standard $\left(10^{8} \mathrm{CFU} / \mathrm{ml}\right)^{24}$. The series of concentration used was $5,4,3,2.5$, $2,1.5,1.25,1,0.75,0.625$ and $0.375 \mathrm{mg} / \mathrm{ml}$ and were prepared by using $95 \%$ ethanol. The $\mathrm{MIC}$ was done at $37^{\circ} \mathrm{C}$, and was recorded after 24 hours of incubation. The MIC was defined as the lowest concentration of extracts at which the microorganism tested did not demonstrate visible growth. Minimum bactericidal concentration (MBC) was defined as the lowest concentration yielding negative subcultures or only one colony.

\section{Antibacterial activity at different temperatures}

The effect of temperature on antibacterial activity of betel leaves extracts was determined by the methods as described by Lee $e t$ al. (2004) ${ }^{27}$. Ethanol extract $(10 \mathrm{~g} / \mathrm{ml})$ of betel leaves were prepared with $95 \%$ ethanol and transferred into different vials. The vials with the betel leaf extract and the negative controls were incubated in shaking water bath (GFL 1083, German) set at $37^{\circ} \mathrm{C}, 50^{\circ} \mathrm{C}, 75^{\circ} \mathrm{C}$, and $100^{\circ} \mathrm{C}$, respectively, for $30 \mathrm{~min}$. The heated betel leaf extracts were cooled down and stored at $4^{\circ} \mathrm{C}$ until use. The antibacterial activity was assayed by the method as described before.

\section{Antibacterial activity at different $p H$ values}

The effect of $\mathrm{pH}$ on the antibacterial activity of the ethanol extract of betel leaf was assayed following the method reported 
previously by Shibata et al. $(1995)^{28}$, and Ohno et al., (2003) ${ }^{29}$ with slight modification. The $50 \mathrm{mM}$ citrate-phosphate buffer $(\mathrm{pH}$ 5.0), 50mM Phosphate buffer ( $\mathrm{pH} 7.0), 20 \mathrm{mM}$ Tris-HCl buffer $(\mathrm{pH}$ 9.0 ) and $20 \mathrm{mM}$ Glycine- $\mathrm{NaOH}$ buffer ( $\mathrm{pH} 10.0$ ) were used in this assay. All the buffers were sterilized by filter sterilization through $0.45 \mathrm{~mm}$ membrane filter and stored at $4^{\circ} \mathrm{C}$ and used within 30 minutes after preparation. The $\mathrm{pH}$ of betel leaf extract was determined with sterile $\mathrm{pH}$ paper strip. At $10 \%$ concentration, $\mathrm{pH}$ of the extract was recorded 7.0. From the stock $(200 \mathrm{mg} / \mathrm{ml})$ solution $10 \mathrm{mg} / \mathrm{ml}$ of ethanol extract of $\mathrm{pH} 5,7,9$ and 10 were prepared by adding measured amount of extract in buffer. Negative control of ethanol (without betel leaf extract) was prepared in buffers at different $\mathrm{pH}$. The antibacterial activity of the ethanol extracts at different $\mathrm{pH}$ was carried out against the test organisms were done by the disc diffusion method.

\section{Evaluation of antibacterial activity}

Antibacterial activity was evaluated by measuring the zones of inhibition in $\mathrm{mm}$ (including the $8 \mathrm{~mm}$ disk) for different $\mathrm{pH}$ with outside slide callipers near the agar surface and the results were recorded. A reading of $8 \mathrm{~mm}$ meant no zone of inhibition. The endpoint was taken as complete inhibition of growth as determined by naked eye. Each extract was tested in triplicate and assay in this experiment was repeated thrice.

\section{Statistic analysis}

The inhibition zones were calculated as means \pm S.D $(n=3)$. The significance among different data was evaluated by analysis of variance (ANOVA) using the Microsoft Excel
Program. Significant differences in the data were established by least significant difference at the $5 \%$ level of significance.

\section{Results}

Screening of ethanol extract of betel leaves for antibacterial activity against food borne pathogens

Ethanol extract of betel leaf was found to have antibacterial activity against Vibrio cholerae ATCC 6395, E. coli ATCC 25922, S. aureus ATCC 25923, E. coli O157:H7 NCTC 12049, and S. dysenteriae-1 MJ-84. Antibacterial activity of the betel leaf extract was compared with ciprofloxacin (30mg), that was considered as positive control (Fig 1).

Comparative analysis of the antibacterial activity against different organisms is shown in Fig 2. Ethanol extract showed good inhibitory activity against all organisms of interest with zones of inhibition ranging from 12.33 to $14.67 \mathrm{~mm}$. The maximum zone of inhibition was observed against $S$. aureus $(14.67 \mathrm{~mm})$ and minimum against $S$. dysenteriae $(12.33 \mathrm{~mm})$.

\section{$M I C$ and $M B C$}

The results of MIC of ethanol extract of betel leaf against different test organisms are shown in Fig 3. From the experimental findings it was observed that the MIC values for ethanol extract against the test organisms ranged from 0.625 to $0.75 \mathrm{mg} / \mathrm{ml}$. The MIC of the ethanol extract showed highest inhibition for $E$. coli $(0.625 \mathrm{mg} / \mathrm{ml})$, V. cholerae $(0.625 \mathrm{mg} / \mathrm{ml})$ and $S$. aureus $(0.625 \mathrm{mg} / \mathrm{ml})$. The MIC of the ethanol extract showed lowest inhibition for E. coli 0157:H7 $(0.75 \mathrm{mg} / \mathrm{ml})$ and $S$. dysenteriae $(0.75 \mathrm{mg} / \mathrm{ml})$. MBC values against the test organisms studied were ranged from 0.75 to $1.00(\mathrm{mg} / \mathrm{ml})$.

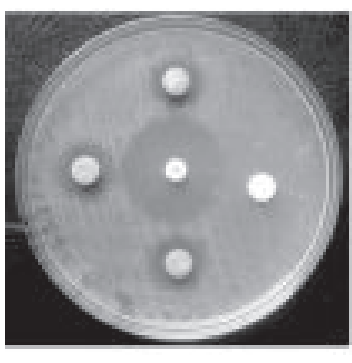

(a)

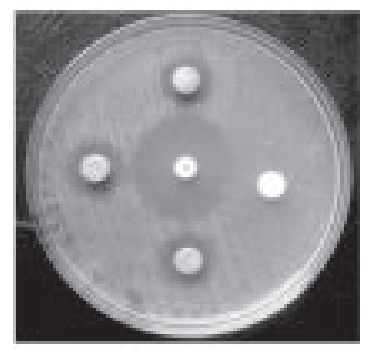

(b)

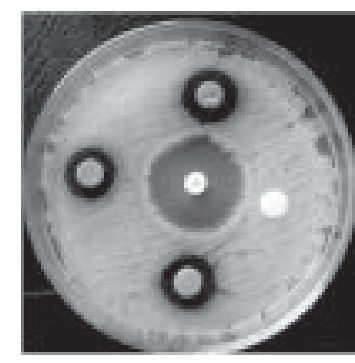

(c)

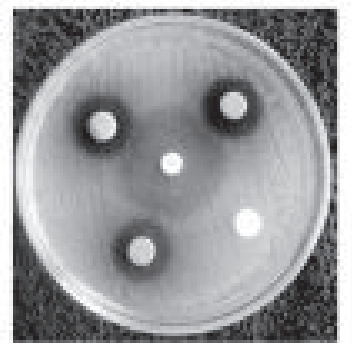

(d)

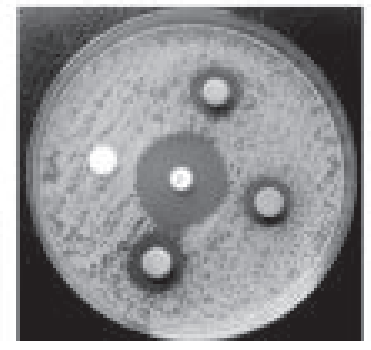

(e)

Figure 1. Ethanol extract from betel leaf showing antibacterial activity by clear zone around the discs against different bacterial strain, respectively (a) S. aureus ATCC 25923, (b) E. coli ATCC 25922, (c) S. dysenteriae-1 Mj-84, (d) E. coli O157:H7 NCTC 12049, and (e) V. cholera ATCC 6395. Central disc represents the positive control (ciprofloxacin) and the disc around which no clear zone was detected represents the negative control (disc with no extract) 
Ethanol extract

Ciprofloxacin

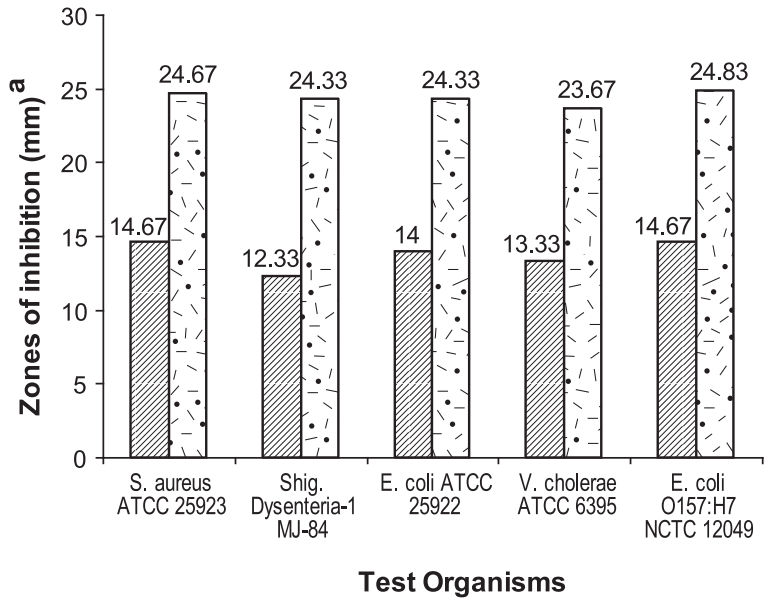

Figure 2. Comparative analysis of antibacterial activity of ethanol extract and essential oil with Ciprofloxacin as standard inhibitor. ${ }^{a}$ Represents mean $\pm S . D .(n=3) ; p>0.05$. Vertical bars indicate the values of standard deviation.

\section{Effect of temperature and $\mathrm{pH}$ on antibacterial activity}

Temperature and $\mathrm{pH}$ were found to have little influence over the antibacterial activity of the betel leaf extract. For temperature, activity was found to be the highest at $50^{\circ} \mathrm{C}$ against all test bacterial species and insignificant decrease in activity was observed at $70^{\circ} \mathrm{C}$ and $100^{\circ} \mathrm{C}$ (Table 1).

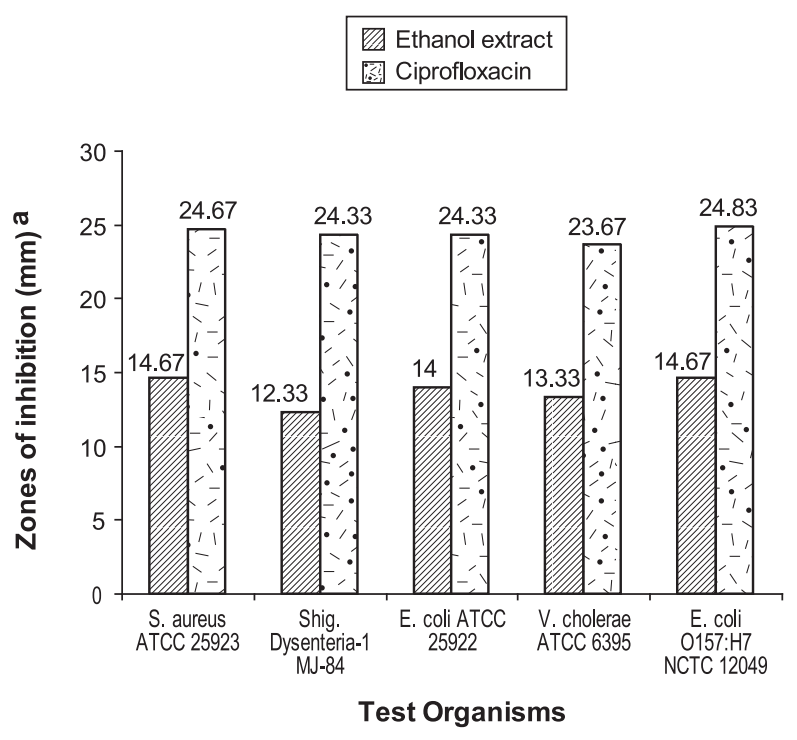

Figure 3. $M I C$ and $M B C$ values of ethanol extract of betel leaf against different organisms

For $\mathrm{pH}$, antibacterial activity was found to be the highest at neutral $\mathrm{pH}$ for most of the test organisms (Table 1) except for $S$. aureas. The activity of the extract against $S$. aureas increased gradually to alkaline $\mathrm{pH}$. Significant decrease in activity was found against Escherichia coli and $S$. dysenterae-1 at $\mathrm{pH} 10.0$ than at $\mathrm{pH} 7.0$.

Table 1. Effect of temperature and $\mathrm{pH}$ on antibacterial activity of ethanol extract (50ml/disc from $10 \mathrm{mg} / \mathrm{ml} \mathrm{solution})$ of betel leaf against some food borne pathogens.

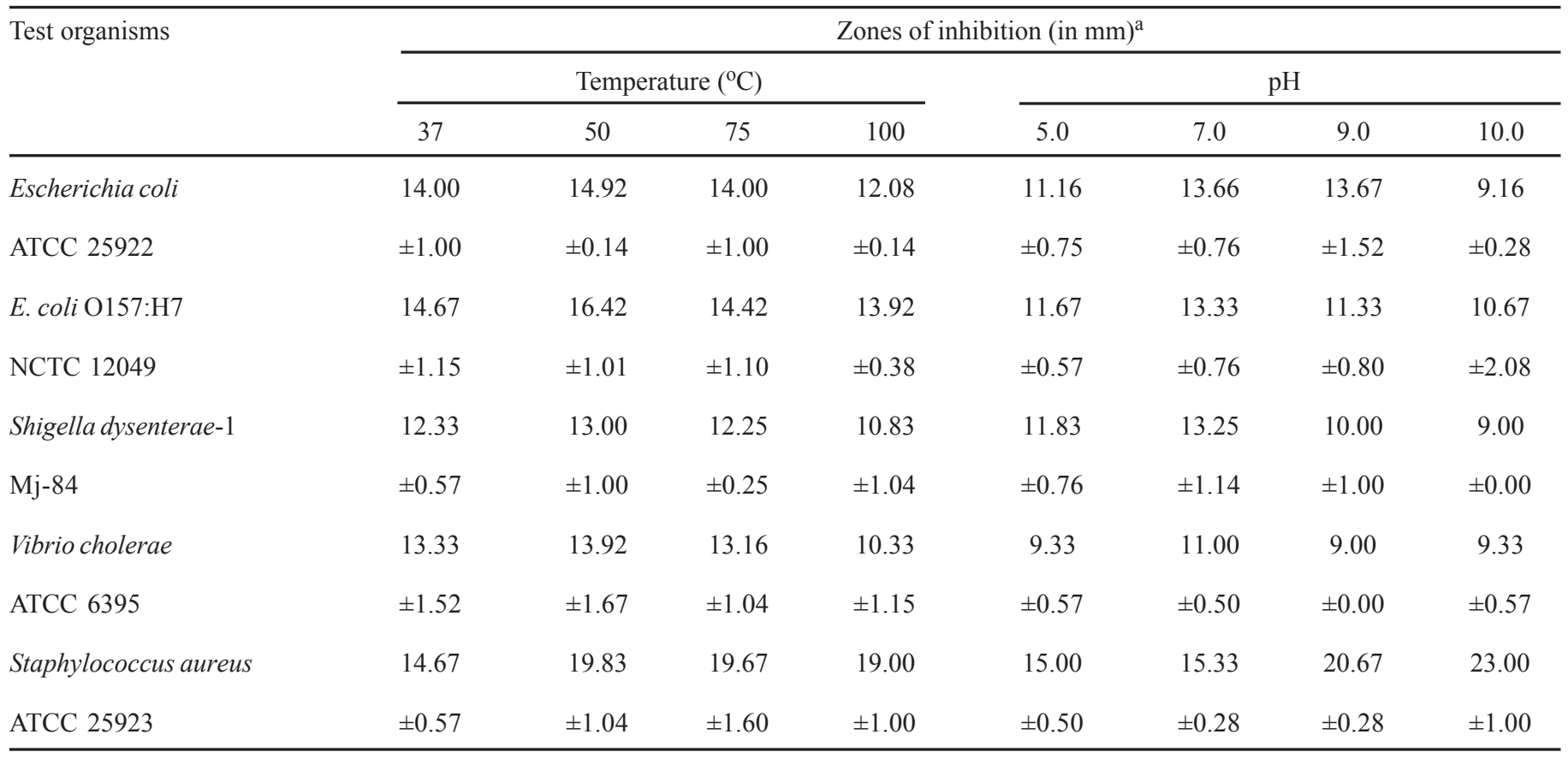

${ }^{a}$ Represents mean \pm S.D. $m m(n=3) ; p>0.05$ 


\section{Discussion}

Natural products are in great demand for their extensive biological properties and bioactive components which had been proved to be useful against large number of causative agents of diseases. It has been proved that extracts of betel leaf showed wide array of activities like antibacterial, antioxidative and antihaemolytic ${ }^{30}$.

In this study, ethanol extract was prepared and tested against 5 food borne pathogens and their MIC and MBC were determined.

In the disc diffusion method, negative control did not show any antibacterial activity for all the five organisms studied. The results presented in Figs. 1 and 2 are the indications of marked antibacterial activity of ethanol extract. The diameter of the zones of inhibition obtained by the ethanol extract of the betel leaf in comparison to those imputed by commonly used antibiotic ciprofloxacin $(30 \mu \mathrm{g} / \mathrm{disc})$ used as standard, were found to be significant. Ethanol extract of betel leaf showed maximum inhibition for $E$. coli $\mathrm{O} 157: \mathrm{H7}(14.67 \pm 1.15 \mathrm{~mm})$ and $S$. aureus (14.67 $\pm 0.57 \mathrm{~mm})$. Datta, et al. (2011) ${ }^{11}$ applied ethanol extract of betel leaves against both Gram positive and Gram negative pathogens and found significant activity especially against $S$. aureus $(13.0 \pm 0.43 \mathrm{~mm})$ which supported the results of the present investigation especially for $S$. aureus $(14.67 \pm 0.57 \mathrm{~mm})$.

MIC of ethanol extract was determined by broth dilution method. MIC values of ethanol extract for the test organisms were ranged from 0.625 to $0.75 \mathrm{mg} / \mathrm{ml}$. The MIC of ethanol extract showed the highest inhibition for E. coli, V. cholerae and S. aureus $(0.625 \mathrm{mg} /$ $\mathrm{ml}$ ) and the lowest inhibition for $E$. coli $\mathrm{O} 157: \mathrm{H} 7$ and S. dysentery was at $0.75 \mathrm{mg} / \mathrm{ml}$.

The effect of temperature and $\mathrm{pH}$ on antibacterial activity of the extract was also determined in this study. The antibacterial activity of this extract was found at all temperatures employed (Table 1) suggesting that the extract were not destroyed at high temperature even at $100^{\circ} \mathrm{C}$ after $30 \mathrm{~min}$ treatment. The diameter of the zones of inhibition was almost similar (with a little variation) up to $75^{\circ} \mathrm{C}$ and at $100^{\circ} \mathrm{C}$ it showed some decrease in the activity.

The ethanol extract of the betel leaves treated at different $\mathrm{pH}$ (5.0 to 10.0 ), showed decrease in activity against the test organisms with the increase in alkalinity except for $S$. aureus where increase in activity at $\mathrm{pH} 10.0(23.0 \pm 1.0 \mathrm{~mm})$ was observed.

It would be advantageous to standardize the methods of extraction and in vitro testing so that the research could be more systemic and interpretation of results would be facilitated. The synergistic effect from the association of antibiotic with plant extracts against resistant bacteria leads to new choices for the treatment of infectious diseases, too. This effect enables the use of the respective antibiotic when it is no longer effective by itself during therapeutic treatment.

\section{Conclusion}

Ethanol extract showed antibacterial activity against some selected food borne pathogens and spoilage microorganisms.
The result also suggests that betel leaf extract possess compounds containing antibacterial properties that can be useful to control food borne pathogens. Antibacterial properties of ethanol extract obtained from betel leaf would be fruitfully utilized in food or food products to extend their shelf-life. As the main concern of this study was to search some plants with excellent antimicrobial activity, the betel leaf may prove to be a beneficial invention since it is cultivated in a large amount in Bangladesh.

\section{Acknowledgement}

This work has been carried out with the financial support by UNU and Kirin, Japan. We like to express our sincere gratitude and appreciation to UNU, Kirin, and all staffs of the Department of Microbiology, University of Dhaka for their supports as well as test organisms and ICDDR'B especially for the organisms.

\section{References}

1. Lee S, Shin DS, Kim JS, Oh KB and Kang SS. (2003). Antibacterial Coumarins from Angelica gigas Roots. Arch Pharm Res. 26: 449.

2. Yuan R, and Lin AY. (2005). Traditional Chinese Medicine. http://qijournal.com/tcm.asp. http://www.aworldofaromatherapy.com/ Essential oils

3. Loper JE, Henkels MD, Roberts RG, Grove GG, Willett MJ and Smith TJ. 1999. Evaluation of streptomycin, oxatetracycline, and copper resistance of Erwinia amylovora isolated from pear orchards in Washington State. Plant Dis. 75: 287-290.

4. Davis J. 1994. Inactivation of antibiotics and the dissemination of resistance gene. Science. 264:375-382.

5. Service RF. 1995. Antibiotics that resist resistance. Science. 270:724727.

6. Chiu CH, Wu TL, Su LH, Chu C, Chia JH, Kuo AJ, Chien MS and Lin TY. 2002. The emergence in Taiwan of fluoroquinolone resistance in Salmonella enterica serotype Choleraesuis. $N$ Engl J Med. 346: 413-419.

7. Boonmar S, Bangtrakulnonth A, Pornruangwong S, Samosornsuk S, Kaneko K and Ogawa M. 1998. Significant increase in antibiotic resistance of Salmonella isolates from human beings and chicken meat in Thailand. Vet Microbiol. 62: 73-80.

8. Davis MA, Hancock DD, Besser TE, Rice DH, Gay JM, Gay C, Gearhart L and DiGiacomo R. 1999. Changes in antimicrobial resistance among Salmonella enterica serovar Typhimurium isolates from humans and cattle in the Northwestern United States, 19821997. Emerg Infect Dis 5: 802-806.

9. Threlfall EJ, Ward LR, Frost JA and Willshaw GA. 2000. The emergence and spread of antibiotic resistance in food-borne bacteria. Int $J$ Food Microbiol.

62: $1-5$.

10. Cordell GA. 2000. Bioderversity and drug discovery a symbiotic relationship. Phytochem. 55: 463-480.

11. Datta A, Ghoshdastidar A, and Singh M. 2011. Antimicrobial Property of Piper betel Leaf against Clinical Isolates of Bacteria. Int J Pharma Sci and Res. 2: 104-109.

12. Jana BL. 1996. Improved technology for betel leaf cultivation. A paper presented in the "Seminar-cum-Workshop on Betel leaf Marketing", held at State cashew nut farm,Directorate of Agricultural Marketing, Digha, Midnapur (W. B.), India, June 5-6, 1996.

13. Khoshoo TN. 1981: Welcome address, pp. xvii-xx, In: Proc. of Group Discussion on Improvement of Betelvine Cultivation. S.D. Khanduja and V.R. Balasubrahmanyam (Eds.). National Botanical Research Institute, Lucknow, India. 
14. Samanta C. 1994. Paan chaser samasyabali-o-samadhan: Ekti samikkha (In Bengali): "A Report on the Problems and Solutions of Betel Vine Cultivation". A booklet published by Mr. H. R. Adhikari, C-2/16, Karunamoyee, Salt Lake City, Kolkata-64 (WB), India.

15. Sharma ML, Rawat AKS, Khanna RK, Chowdhury AR and Raina RM. 1996. Flavour characteristics of betel leaves. Euro Cosmetics. 5: 2224.

16. CSIR. 1969. (Council of Scientific and Industrial Research, New Delhi): The Wealth of India, 8: 84-94. CSIR, New Delhi.

17. Guha P. 2006. Betel Leaf: The Neglected Green Gold of India. J Hum Ecol. 19: 87-93.

18. Caburian AB and Osi MO. 2010. Characterization and Evaluation of Antimicrobial Activity of the Essential Oil from the Leaves of Piper betle L. Int Sci Res J. 2: 1-13.

19. Jenie, BSL. (2001). Antimicrobial Activity of Piper betle Linn Extract towards Foodborne Pathogens and Food Spoilage Microorganisms, FT Annual Meeting, New Orleans, Louisiana.

20. Caceres A., Cano O, Samayoa B, Aguilar L. 1990. Plants used in Guatemala for treatment of gastrointestinal disorders 1. Screening of 84 plants against Enterobacteria. J Ethnopharmaco. 30: 55-73.

21. Meyer JJM, Afolayan AJ, Taylor, MB, Engelbrecht L. 1996. Inhibition of herpes simplex virus type 1 by aqueous extracts from shoots of Helichrysum aureonitens (Asteraceae). J Ethnopharmaco. 52: 4143

22. Chopra R.N, Nayar SL and Chopra IC. 1956. Glossary of Indian Medicinal Plants, pp.194. CSIR, New Delhi.
23. Khanra S. 1997. Paan Vittik Silpakendra (In Bengali). "Betel Leaf Based Industry". Nabanna Bharati, 30(2): 169.

24. Jorgensen JH, Turnide JD and Washington JA. 1999. Antibacterial susceptibility taste: Dilution and Didk diffusion method. In: Mannual of clinical Microbiology, $7^{\text {th }}$ ed. Murry, PR, Pfaller MA, Tenover FC, Baron EJ. and RH Yolken (eds), ASM Press, Washington, D.C pp. $1526-1543$

25. Bauer AW, Kirby WMM, Sherris JC and Turck M. 1966. Antibiotic sensitivity testing by a standardized single disk method. Am J Clin Pathol. 45: 493-496.

26. Sengul M, Oguteo H, Adeguzel A, Sahin F, Kara AA, Karman I and Gulluce M. 2005. Antimicrobial effects of Verscum georgicum Bentham extract. Turki J Biol. 29: 105-110.

27. Lee CF, Han CK, Tsau JL. 2004. In vitro inhibitory activity of chiness leek extract against Campylobacter species. Int J Food Microbiol. 94: 169-174.

28. Shibata K, Ito Y, Hongo A, Yasoshima A, Endo T and Ohashi M. 1995. Bactericidal activity of a new antiulcer agent, ecabet sodium, against Helicobacter pylori under acidic conditions. Antimicrob Agents Chemother. 39: 1295-1299.

29. Ohno T, Kita M, Yamaka Y, Imamura S, Yamamoto T, Mitsufuji S, Kodama T, Kashima K and Imanishi J. 2003. Antibacterial activity of essential oils against Helicobacter pylori. Helicobacter. 8: 207215 .

30. Chakraborty D and Shah B. 2011. Antimicrobial, Antioxidative and Antihaemolytic Activity of Piper betel L. leaf extracts. Int $J$ Pharmacy and Pharm Sci. 3: 192-198. 